\title{
豚皮脂肪分の準備工程中における変動と リパーゼによる脱脂
}

\author{
岡村 浩*.白扩邦郎**.川村 亮* \\ * 東京濃工大学皮革研究抬設, 東京都 183 \\ ** 山崎化学研究所, 埼玉徂 340
}

(1974. 5. 17 受付)

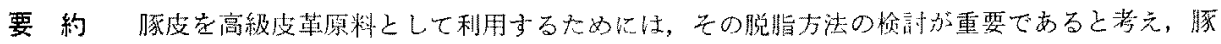
皮脂肪分の集備工程中の变動を明らかにし，リペーゼを使朋しての脱脂を試みた。豚皮は脂肪分を20\% 以上含有しており，牛皮にくらべ著しく多い，脂肪分の部位に上る変勳は比校的少ないが，通常の㳊倩 工程を終了しても6\%程度残留し，とくに程蔵皮が半乾状熊になると脂肪分は除去さ机にくい，再石灰

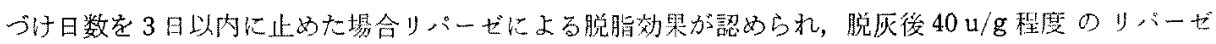
を添加してドラム中で回転すると脂肪分は3\%程度志でに減少させることができた。
\end{abstract}

我が国における豚原皮の供給能力は大きいので，国産 でまかなえる原料皮としての豚皮の重要性は大きい，海 外で台湾は我が国と似たような事情にある。近年豚皮 を高級皮革製品の原料皮として活用子る試みが多くなさ れているが，組織の瀻維構造における部位愿が大きいこ とが問題点の1つとなっている1。. また脂肪念量が多い

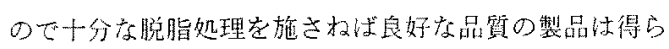
九ない，本研究では豚皮の隻偖工程に出ける脂肪含量の 変動を検し，脱脂手段としてリハーゼによる醅素処理を 試正店。

\section{供試材料と試験方法}

1. 豚皮上リパーゼ

日本産上台清産の豚皮は性状が近いのて，豚皮の試料 として台澺, 台南県産の新鮮皮 (平均重星 $4.0 \sim 4.5 \mathrm{~kg}$ )

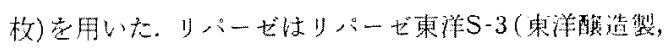
Chromobacterium visucosum var. paralipolyticum $の$ 培養液加ら得た）を使用した。为価はリパーぜ活性 3000 u/g(カリープ油〜ポリピニールアルコール法2゙による), ブロテアーぜ活性 $35 \mathrm{pu} / \mathrm{g}$ (ANSON-获综变法3)による)で ある。

\section{2. 潗備作業の赦件}

豚皮鞣梨の澡備の諸工程で全脂量がどのように装動す

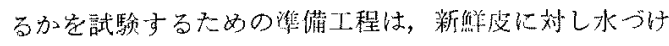
から脱灰・ベーチンダ亦での処理在下記の上う比施し

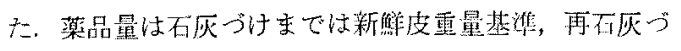
け以後法裸皮重量基激で示した。
水つけ：5倍量の 10\%程化ナトリウム溶液老使用し， ドラム内中で 3 洔間回転したのち 20 分間水洗した。

石灰づけ：水 $250 \%$ ，水酸化カルシウム $4 \%$ 打よび硫 化ナトリウム(フレータ）3.6\% 使用し，ドラム中で 40 分蘭でとに 10 分間回耺し 3 時間継続した.ついで 3 時間

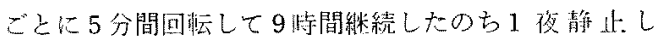
た.この後 20 分間水洗してかららスプリッティングマシン を用いて厚さ老 2.2 2.3 $\mathrm{mm}$ に調整し，裸皮重量起測定 Lt.

再石灰一㚈：2\%水酸化カルシウム溶洐 200\% 之非イ

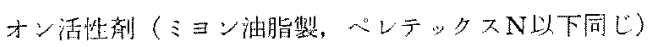
$0.1 \%$ を使朋し，ドラム中で 20 分間回枟した後 8 時間で

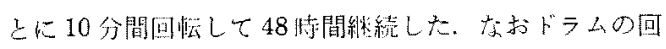
転速度は 4 r.p.m. とした

脱灰・ベーチンダ：水 $(35$ C $) 200 \%$ 己乳酸 $0.3 \%$ 含 屯浴中で 10 分間回怰し，同浴中心硫酸ナンモ二ウム 0.8

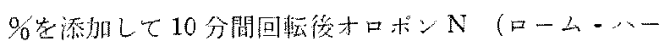
又社製) $0.1 \%$ 添加Lて2 㭙閒间䡮し，20 分間水洗し た。

\section{3. 眝藏条件}

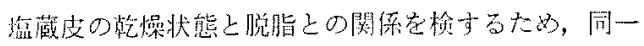

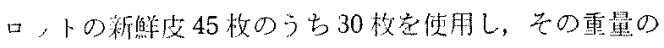

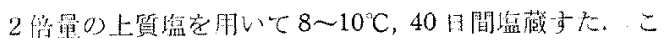

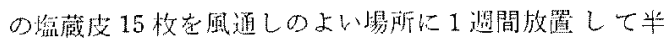

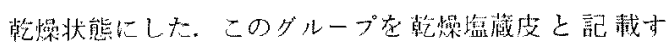

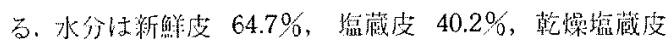

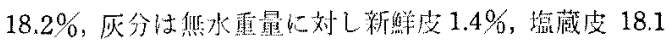


\%乾燥塭蔵皮 $18.6 \%$ であった。

4. 小皮片に刘するリパーゼ処琟

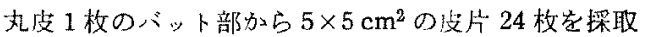
し，これを 4 枚ずつ 6 グループに分けた. 各皮片の 1/4 苍切断しグループでとにまとめて細切混合し，リパーゼ による処理前の脂肪含量を測定した，残りの皮片を直焦 $35 \mathrm{~cm}$ のガラス製テストドラム抽， $0.01 \mathrm{M}$ リン酸綏衝 溶液 ( $\mathrm{pH} 7.0$, 温度 $35^{\circ} \mathrm{C}$ ) $200 \%$ と战に 10 分間回轱し， ついで所定量のリパーゼを添加し（絬果の 4. 参照）2時 間回枟続けた後冷水で洗浮した. 好理後皮片安細切混 合し脂肪含量測定した.

5. 脂肪含量の測定

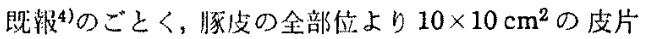
を採取し，垻酸分解後のエチルエーテル抽出量を脂肪含 埋とした。

\section{実験方法，実験結果および考察}

\section{1. 啋我中脂肪分の部位的分流}

新鮮皮の敵面に付着した脂肪艺十分に除去したもの1 枚技よび脂肪の除去が不十分なもの1枚定選び，全面各

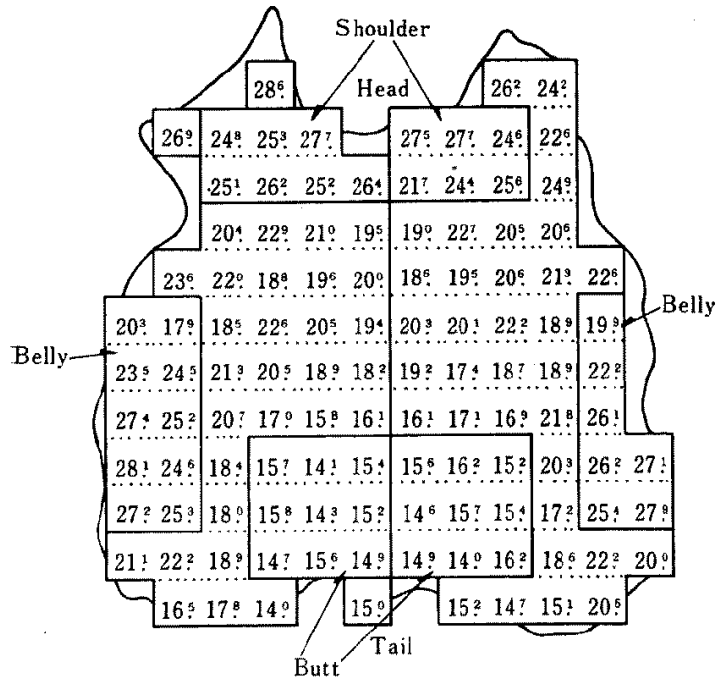

\begin{tabular}{lcccc} 
Location & \multicolumn{5}{c}{ Averaged value } \\
\hline Left side & 25.8 & 24.4 & 15.1 & 20.6 \\
Right sight & 24.8 & 24.9 & 15.3 & 20.3
\end{tabular}

Fig. 1. Chart showing variation in fat content of pigskin of which flesh side well degreased over the entire area. The values indicate the fat content in percentage based on the dry weight.

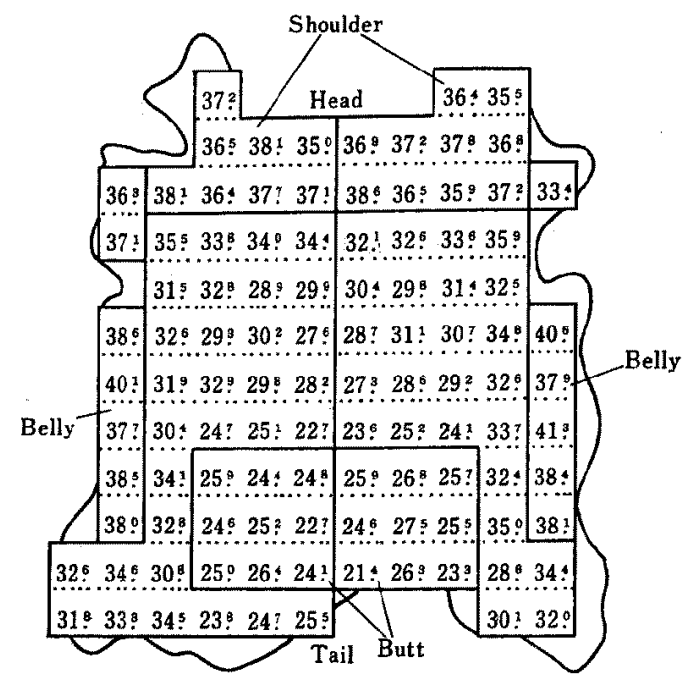

Averaged value

\begin{tabular}{lccccc} 
Location & Shoulder & Belly & Butt & Whole \\
\hline Left side & 38.5 & 38.6 & 24.8 & 31.5 \\
Right side & 37.1 & 39.3 & 25.2 & 31.9 \\
\hline
\end{tabular}

Fig. 2. Chart showing variation in fat content of pigskin of which flesh side partially degreased over the entire area.

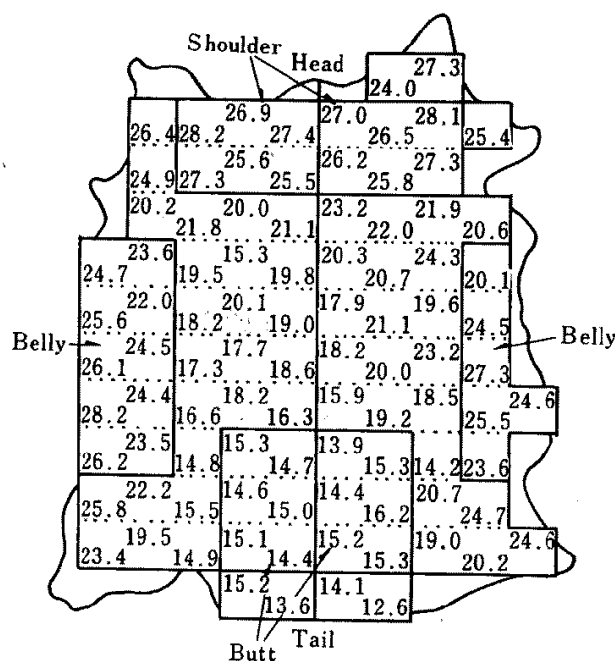

\begin{tabular}{lcccc} 
Location & Shoulder & Belly & Butt & Whole \\
\hline $\begin{array}{c}\text { Left side } \\
\begin{array}{c}\text { (green skin) } \\
\text { Right side }\end{array}\end{array}$ & 26.8 & 25.4 & 14.9 & 20.7 \\
$\begin{array}{c}\text { (soaked) } \\
\text { (soakeraged value }\end{array}$ & 26.8 & 24.2 & 15.1 & 21.1
\end{tabular}

Fig. 3. Change in fat content after soaking of pigskin. The values indicate the fat content in percentage. The left side represents green skin and the right side, soaked skin. 


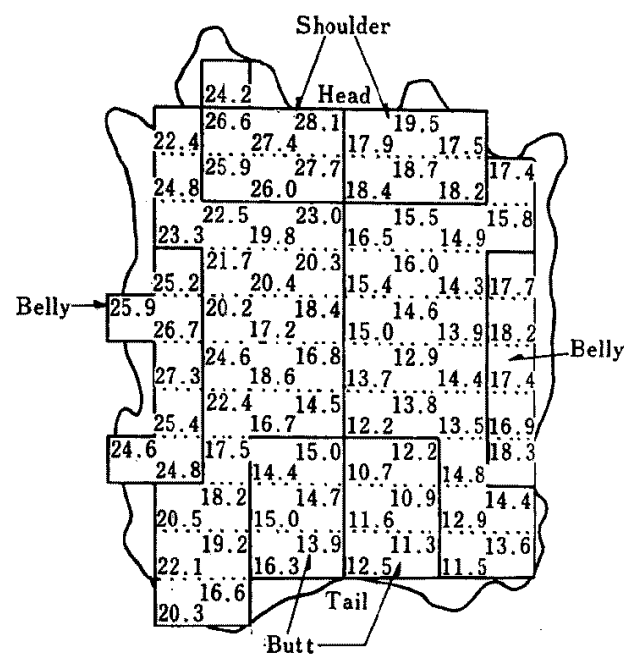

\begin{tabular}{lcccc} 
& \multicolumn{5}{c}{$\begin{array}{c}\text { Averaged value } \\
\text { Location }\end{array}$} & Shoulder & Belly & Butt & Whole \\
\hline $\begin{array}{l}\text { Left side } \\
\text { (soaked skin) }\end{array}$ & 27.0 & 25.7 & 14.8 & 21.3 \\
$\begin{array}{l}\text { Right side } \\
\text { (limed pelt) }\end{array}$ & 18.3 & 17.7 & 11.5 & 14.9 \\
\hline
\end{tabular}

Fig. 4. Change in fat content after liming of pigskin. The values indicate the fat content in percentage. The left side represents soaked skin and the right side, limed pelt.

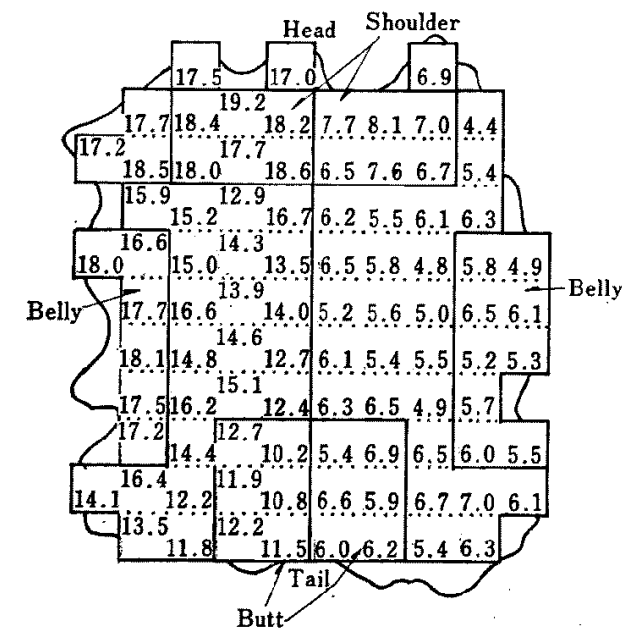

\begin{tabular}{lccccc} 
& \multicolumn{5}{c}{ Averaged value } \\
Location & Shoulder & Belly & Butt & Whole \\
\hline $\begin{array}{l}\text { Left side } \\
\text { (limed pelt) }\end{array}$ & 18.4 & 17.5 & 11.6 & 15.3 \\
$\begin{array}{l}\text { Right side } \\
\text { (relimed pelt) }\end{array}$ & 7.3 & 5.7 & 6.2 & 7.2 \\
\hline
\end{tabular}

Fig. 5. Change in fat content after reliming of pigskin. The values indicate the fat content in percentage. The left side represents limed pelt and the right side, relimed pelt.

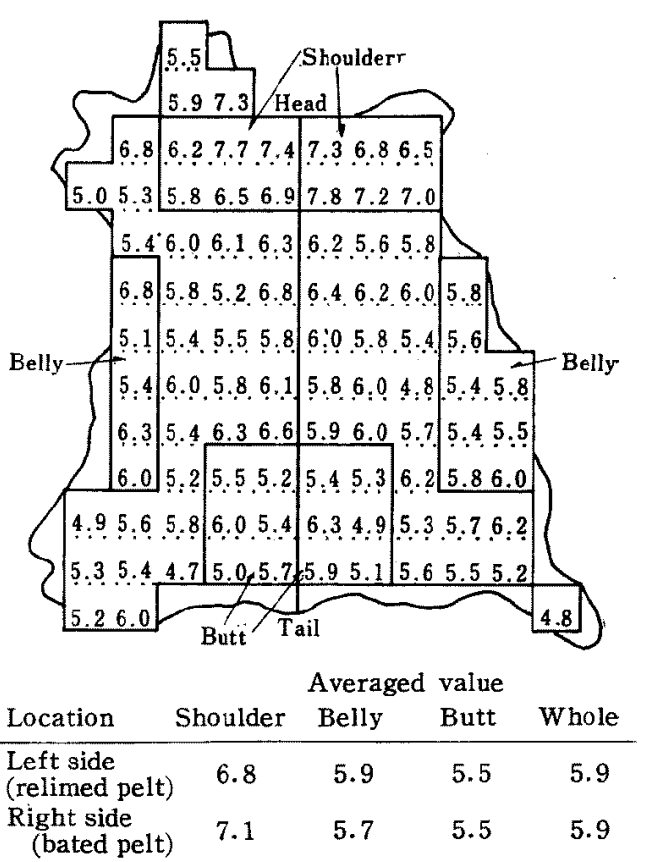

Fig. 6. Change in fat content after bating of pigskin. The values indicate the fat content in percent. The left side represents relimed pelt and the right side, bated pelt.

部位の䁕肪舍量定測定した. 結果をFig. 1 および Fig. 2 . に示す.

豚皮脂肪分は，裏面の脂肪空十分除去しても的 $20 \%$ ， 除去が不十分なるのでは 30\%以上であった。牛皮の場合 多脂性の北米産へビーステア皮 (70 lbs 前後)でも全面平 均の含量は $10 \%$ 程度であるから，豚皮の脂肪分は非常 に多い、バット部はショルダー部, ベリー部よりも約 10 $\%$ 低いが，隣接部位間および左右対照部位間の差異は少 ない、へビーステフ皮に比較すれば部应による変動は少 ないといえる。

\section{2. 準嘴工程中の変化}

网一好友の左半裁を対照とし，右半载は1工程すする。 た段階で脂肪合量を測定した。絬果 Fig. 3，Fig.4， Fig. 5, およびFig. 6 に示す。

各工程で減少した脂肪分をまとめると Table Iのよ うになり，対照（新鮮皮の脂肪分）を $100 \%$ とると心 ッ卜部の境合死灰づけで $22 \%$ ，再石灰づけで $36 \%$ 減 少 していら.ペリー部では石兏づけで $32 \%$, 再石灰づけで

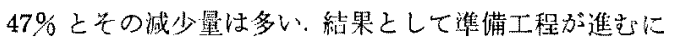
つれてバット部之ベリー部の差異が少なくなる傾向があ。

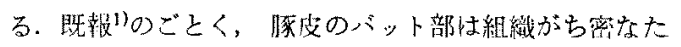


岡村 - 白杫 - 川村

Table 1. Change in fat content of pigskin during beamhouse operations

\begin{tabular}{lrrrr} 
& \multicolumn{4}{c}{ Location } \\
& Shoulder & Belly & Butt & Whole \\
\hline $\begin{array}{l}\text { Fat content of } \\
\text { green skin }\end{array}$ & 26.8 & 25.4 & 14.9 & 20.7 \\
$\begin{array}{l}\text { Change in fat } \\
\text { content during } \\
\quad \text { soaking }\end{array}$ & & & & \\
$\quad \begin{array}{l}\text { liming } \\
\text { reliming }\end{array}$ & -8.7 & -8.0 & -8.8 & -6.4 \\
$\quad$ bating & -11.1 & -11.8 & -5.4 & -8.1 \\
\hline
\end{tabular}

The values are given by fat content in percent based on the dry weight.

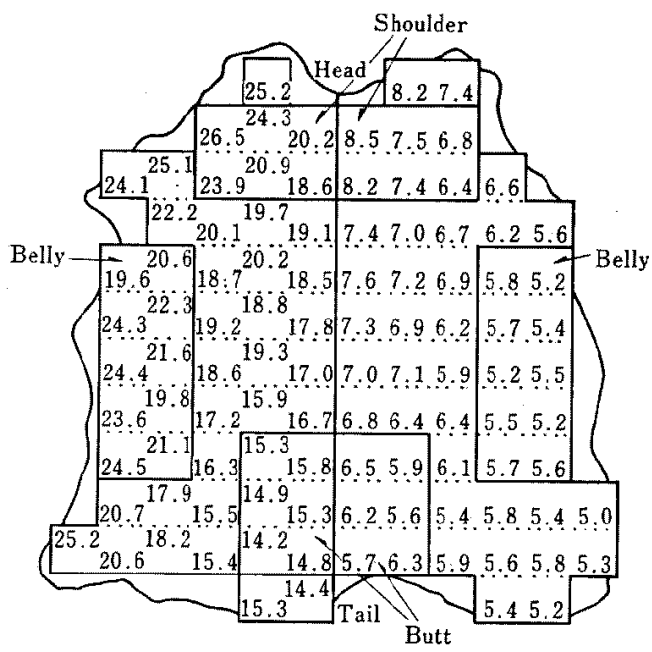

Averaged value

\begin{tabular}{lcccc} 
Location & Shoulder & Belly & Butt & Whole \\
\hline $\begin{array}{l}\text { Left side } \\
\begin{array}{l}\text { (green skin) } \\
\text { Right side }\end{array}\end{array}$ & 22.4 & 22.2 & 15.1 & 19.7 \\
\begin{tabular}{l} 
(bated pelt) \\
\hline
\end{tabular} & 7.5 & 5.5 & 6.0 & 6.3 \\
\hline
\end{tabular}

Fig. 7. Effect of the beamhouse operations upon fat content of green skin. The values indicate the fat content in percent. The left side represents green skin and the right side, bated pelt.

わ，脂肪が移動しにくいことが主な原因と㘼えられる。

3. 眝藏状態の影袈

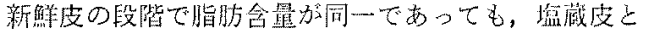

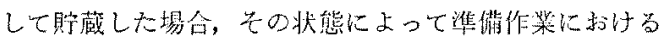

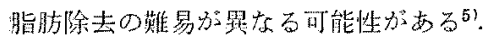

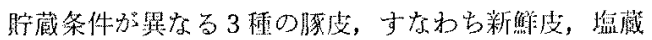

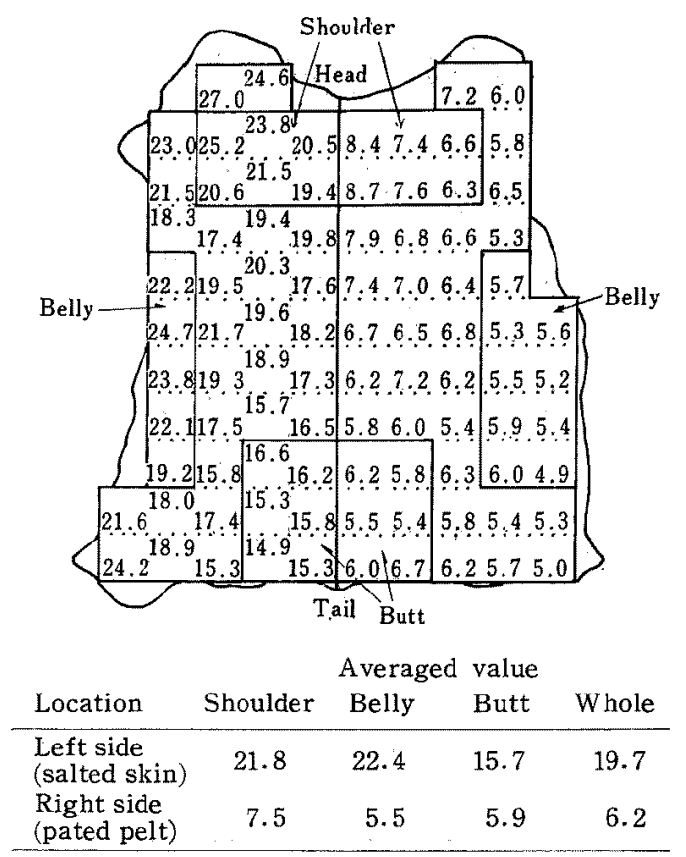

Fig. 8. Effect of beamhouse operations upon fat content of wet salted skin. The values indicate the fat content in percent. The left side represents salted skin and the right side, bated pelt.

皮尔よび乾燥塩藏皮について準借作業による脂肪含量の 変化它比較した，左半裁を対照として準備作業を施さ ず，右半裁はベーチングまでの処理を施した後脂肪含量 堂測定した. 結果定Fig. 7,Fig. 8 および Fig. 9 に示 ఫे.

×ット部の平均値で準倩工程中の脂肪含量の减少率安

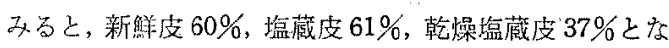

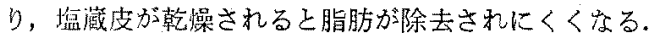

4. 小皮片によるリパーゼの効果の検討

まずリパーゼの添加量を検討した，脱死までの準備作

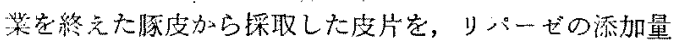
を敬燥皮重量に対し $10 \mathrm{u} / \mathrm{g}, 20 \mathrm{u} / \mathrm{g}, 40 \mathrm{u} / \mathrm{g}, 60 \mathrm{u} / \mathrm{g}$ ， $80 \mathrm{u} / \mathrm{g}$ おび $100 \mathrm{u} / \mathrm{g}$ のよう 6 段階に変化させてり ペーゼ妈理老行った. 処理前後の脂肪含量から脱脂率を 求名，同じ実歌定 2 日くり返して得た結果をFig. 10 に 示守.

リバーゼによる脱脂教舀は添加量 $40 \mathrm{u} / \mathrm{g}$ までは㥀線 的に上昇し，これ以上になると勃果がやや減少する。 し たがってリパーぜの使用は $40 \mathrm{u} / \mathrm{g}$ が適当と考えた。

再石灰つけ日数を臣くすれば䋐維組織が台縔してリパ 
豚皮のリペーゼてよる脱脂

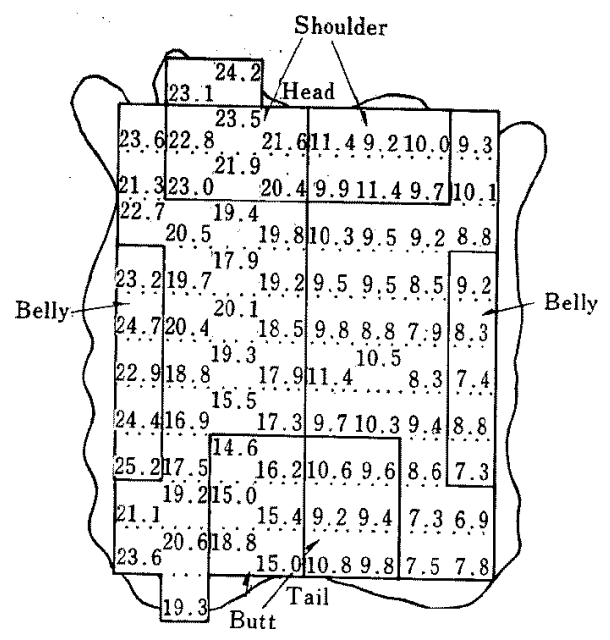

Averaged value

\begin{tabular}{ccccc} 
Location & Shoulder & Belly & Butt & Whole \\
\hline $\begin{array}{c}\text { Left side } \\
\text { (dry salted skin) }\end{array}$ & 22.2 & 24.1 & 15.8 & 18.2 \\
$\begin{array}{c}\text { Right side } \\
\text { (bated pelt) }\end{array}$ & 10.3 & 8.2 & 9.9 & 9.3
\end{tabular}

Fig. 9. Effect of beamhouse operations upon fat content of dry salted skin. The values indicate the fat content in percent. The left side represents salted skin and the right side, bated pelt.

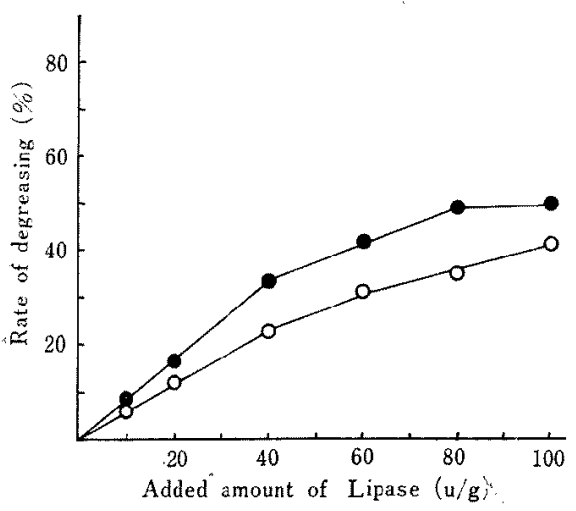

Fig. 10. Influence of added amount of lipase upon degreasing effect. Cut pieces of delimed pelt were treated with the lipase produced by Cromobacterium viscosum var para lipolyticum with a lipase activity of $3000 \mathrm{u} / \mathrm{g}$ and a protease activity of $35 \mathrm{pu} / \mathrm{g}$. The black circles and the white circles indicate the results from two pieces of pigskin.

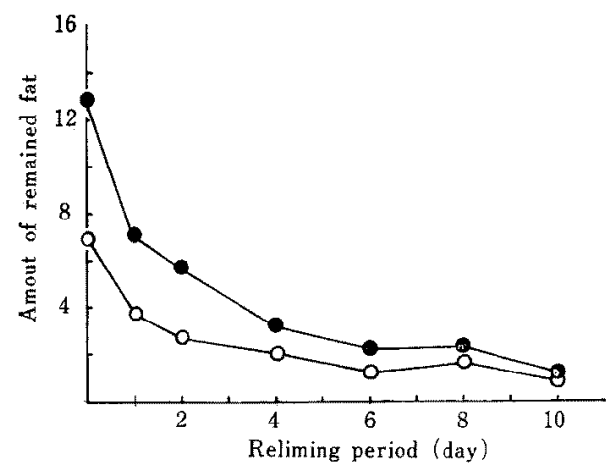

Fig. 11. Influence of reliming upon degreasing effect of lipase. Cut pieces of limed pelt were relimed for various lengths of time and subjected to lipased treatment, indicated by the white circles. The black circles indicate Oropon $\mathrm{N}$ (bate) treament as a control.

一ゼの作用が強をるすと期待される．石敢づけを終え た豚皮 2 枚のベット部より 24 枚ずつ計 48 枚の皮片を採

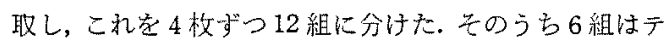
ストトラム定用いて処理日数学 0 日，2日，4日，6日，8 日怙よび10日のように6段階に变化させて再石死づけ 行ったのb脱灰後，リパーゼ姏理を施した（リパーゼ は $40 \mathrm{u} / \mathrm{g}$ 使用した)，残り6組は同様に6 段皆の処理日 数で再石灰づけを行ってから通常の脱灰・ベーチンダを 施して対照とした。、すれの組もこの後水 $\left(35^{\circ} \mathrm{C}\right) 200 \%$ ， 非イオン活性郕 $0.5 \%$ 索使用してドラム中で1時間回転 してふら 30 分間水洗した. 以上の処理後皮片の脂肪含量 を測定した結果をFig. 11 に示す。

再石灰つけ日数が 3 日以内の時, リパーゼの使用効果

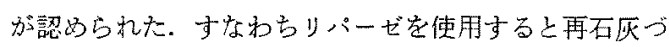
け日数を1〜3日間短箱することができる。

\section{5. 眝藏状態の買なる豚皮の脱脂}

皮片を使用した基験ふら，リパーゼを脱脂手段として 使用しらる可能性学見出した。そこで貯藏状態の買なる

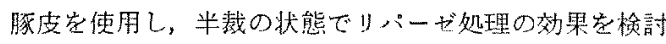
した.

新焦度，程藏皮市よび乾懆塭藏皮を各 9 枚，ベーチン ク゚までの潗備作莱を施した段階で半裁とし，左半裁は対 照としてただらに脂肪含量艺測定した，右半裁は 3 枚ず

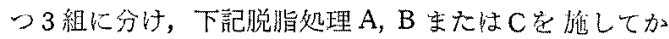
ら脂肪含量を測定した。な和桬品量はーーチンダ後の皮 重量定基集として亦した.

$\mathrm{A}$ ：水 $\left(35 \sim 36^{\circ} \mathrm{C}\right) 200 \%$, 非イオン活性剤 $0.8 \%$ と共 にドラム中で 40 分間回転してから 20 分間水洗. 
岡村・白事・川村

Table 2. Effect of various methods of degreasing treatments upon the fat content of bated pelt from green pigskin. The left side indicates the value before degreasing and the right side, the value after degreasing. The values are indicated in percent based on the dry weight.

\begin{tabular}{|c|c|c|c|c|c|c|c|c|c|}
\hline \multirow{2}{*}{$\begin{array}{c}\text { Method of degreasing } \\
\text { treatment }\end{array}$} & \multirow{2}{*}{ Location } & \multicolumn{2}{|c|}{ Skin I } & \multicolumn{2}{|c|}{ Skin II } & \multicolumn{2}{|c|}{ Skin III } & \multicolumn{2}{|c|}{ Average } \\
\hline & & left & right & left & right & left & right & left & right \\
\hline \multirow{5}{*}{$\begin{array}{l}\text { A. with nonionic } \\
\text { surfactant }\end{array}$} & shoulder & 6.5 & 2.6 & 6.7 & 2.2 & 6.4 & 2.4 & & \\
\hline & belly & 5.8 & 1.7 & 5.4 & 1.4 & 5.3 & 1.5 & & \\
\hline & butt & 6.0 & 2.0 & 6.3 & 2.0 & 6.1 & 2.3 & & \\
\hline & whole & 6.1 & 2.1 & 6.1 & 1.9 & 5.9 & 2.1 & 6.0 & 2.0 \\
\hline & shoulder & 6.9 & 1.4 & 6.6 & 1.2 & 7.2 & 1.9 & & \\
\hline \multirow{4}{*}{$\begin{array}{l}\text { B. with kerosine } \\
\text { and nonionic } \\
\text { surfactant }\end{array}$} & belly & 5.8 & 0.9 & 5.8 & 0.7 & 6.1 & 0.8 & & \\
\hline & butt & 5.6 & 1.4 & 6.2 & 1.2 & 5.8 & 1.6 & & \\
\hline & whole & 6.1 & 1.2 & 6.2 & 1.0 & 6.4 & 1.4 & 6.2 & 1.2 \\
\hline & shoulder & 7.0 & 2.0 & 6.8 & 1.6 & 6.2 & 2.1 & & \\
\hline \multirow{3}{*}{$\begin{array}{l}\text { C. with lipase } \\
\text { and nonionic } \\
\text { surfactant }\end{array}$} & belly & 6.2 & 1.3 & 5.8 & 1.1 & 5.5 & 0.8 & & \\
\hline & butt & 5.8 & 1.8 & 6.0 & 1.6 & 5.6 & 1.8 & & \\
\hline & whole & 6.3 & 1.7 & 6.2 & 1.4 & 5.8 & 1.6 & 6.1 & 1.6 \\
\hline
\end{tabular}

Table 3. Effect of various methods of degreasing treatments upon the fat content of bated pelt from wet salted pigskin. The left side indicates the value before degreasing and the right side, the value after degreasing. The values are indicated in percent based on the dry weight.

\begin{tabular}{|c|c|c|c|c|c|c|c|c|c|}
\hline \multirow{2}{*}{$\begin{array}{l}\text { Method of degreasing } \\
\text { treatment }\end{array}$} & \multirow{2}{*}{ Location } & \multicolumn{2}{|c|}{ Skin I } & \multicolumn{2}{|c|}{ Skin II } & \multicolumn{2}{|c|}{ Skin III } & \multicolumn{2}{|c|}{ Average } \\
\hline & & left & right & left & right & left & right & left & right \\
\hline \multirow{4}{*}{$\begin{array}{l}\text { A. with nonionic } \\
\text { surfactant }\end{array}$} & shoulder & 7.3 & 2.9 & 6.4 & 2.4 & 6.8 & 2.6 & & \\
\hline & belly & 5.4 & 1.8 & 5.6 & 1.6 & 5.6 & 2.0 & & \\
\hline & butt & 6.0 & 2.1 & 6.2 & 1.9 & 5.8 & 2.4 & & \\
\hline & whole & 6.2 & 2.3 & 6.1 & 2.0 & 6.1 & 2.3 & 6.1 & 2.2 \\
\hline \multirow{4}{*}{$\begin{array}{l}\text { B. with kerosine } \\
\text { and nonionic } \\
\text { surfactant }\end{array}$} & shoulder & 6.6 & 1.2 & 6.2 & 1.1 & 6.8 & $1 \cdot 4$ & & \\
\hline & belly & 5.3 & 0.7 & 5.7 & 0.5 & 5.4 & 0.8 & & \\
\hline & butt & 5.6 & 1.1 & 6.0 & 1.0 & 5.6 & 1.4 & & \\
\hline & whole & 5.8 & 1.0 & 6.0 & 0.9 & 5.9 & 1.2 & 5.9 & 1.0 \\
\hline \multirow{4}{*}{$\begin{array}{l}\text { C. with lipase } \\
\text { and nonionic } \\
\text { surfactant }\end{array}$} & shoulder & 7.0 & 1.4 & 6.8 & 1.7 & 6.6 & 2.0 & & \\
\hline & belly & 5.8 & 1.3 & 5.4 & 0.9 & 5.5 & 1.4 & & \\
\hline & butt & 5.4 & 1.6 & 5.8 & 1.4 & 6.0 & 1.8 & & \\
\hline & whole & 6.1 & 1.4 & 6.0 & 1.3 & 6.0 & 1.7 & 6.0 & 1.5 \\
\hline
\end{tabular}

B：ケロシン10\%，非イオン活性剂 $1.5 \%$ と期に 1 洔 間ドラム畃で回軾,引続き水 $\left(25 \sim 30^{\circ} \mathrm{C}\right) 100 \%$ 老添加し て 30 分間回転を継絖してから 30 分間水洗.

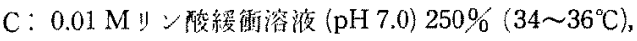
非イオン活性剂 $0.4 \%$ と其にドラム中で 10 分間回転後,

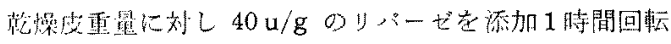
苑継続，ついで 30 分間水洗.
脱脂処理前後の脂肪含量它 Table 2, Table 3 拉よび Table 4 に示す.

脂肪合量の減少割合は $\mathrm{B}>\mathrm{C}>\mathrm{A}$ であるが，とくに乾 燥堭蔵皮の場合に $\mathrm{B} \fallingdotseq \mathrm{C}>\mathrm{A}$ となり，リパーゼはケロシ ンに近い奻果を示した。

6. リハヘーゼを俅用する脱脂工程の梌副

范燥盖成皮中の脂肪は除去されにくいので，これ刘 
豚皮のリパーゼによる脱脂

Table 4. Effect of various methods of degreasing treatments upon the fat content of bated pelt from dry salted pigskin. The left side indicates the value before degreasing and the right side, the value after degreasing. The values are given in percent based on the dry weight.

\begin{tabular}{|c|c|c|c|c|c|c|c|c|c|}
\hline \multirow{2}{*}{$\begin{array}{c}\text { Method of degreasing } \\
\text { treatment }\end{array}$} & \multirow{2}{*}{ Location } & \multicolumn{2}{|c|}{ Skin I } & \multicolumn{2}{|c|}{ Skin II } & \multicolumn{2}{|c|}{ Skin III } & \multicolumn{2}{|c|}{ Average } \\
\hline & & left & right & left & right & left & right & left & right \\
\hline \multirow{4}{*}{$\begin{array}{l}\text { A. with nonionic } \\
\text { surfactant }\end{array}$} & shoulder & 9.8 & 4.6 & 10.3 & 4.8 & 10.1 & 4.2 & & \\
\hline & belly & 7.9 & 3.8 & 8.2 & 3.5 & 7.8 & 3.2 & & \\
\hline & butt & 8.4 & 4.0 & 8.6 & 4.2 & 8.2 & 3.6 & & \\
\hline & whole & 8.7 & 4.1 & 9.0 & 4.2 & 8.7 & 3.7 & 8.8 & 4.0 \\
\hline \multirow{4}{*}{$\begin{array}{l}\text { B. with kerosine } \\
\text { and nonionic } \\
\text { surfactant }\end{array}$} & shoulder & 10.5 & 2.4 & 9.7 & 2.6 & 9.8 & 2.0 & & \\
\hline & belly & 8.3 & 1.8 & 7.6 & 1.5 & 7.4 & 1.4 & & \\
\hline & butt & 8.8 & 2.1 & 8.2 & 1.8 & 8.0 & 1.6 & & \\
\hline & whole & 9.2 & 2.1 & 8.5 & 2.0 & 8.4 & 1.7 & 8.7 & 1.9 \\
\hline \multirow{4}{*}{$\begin{array}{l}\text { C. with lipase } \\
\text { and nonionic } \\
\text { surfactant }\end{array}$} & shoulder & 11.2 & 3.2 & 10.2 & 2.6 & 9.6 & 3.0 & & \\
\hline & belly & 8.8 & 2.2 & 7.8 & 1.8 & 7.3 & 2.2 & & \\
\hline & butt & 8.4 & 2.5 & 8.2 & 1.4 & 7.6 & 1.9 & & \\
\hline & whole & 9.5 & 2.6 & 8.7 & 1.9 & 8.2 & 2.4 & 8.8 & 2.3 \\
\hline
\end{tabular}

Table 5. Comparison of the effect of four different degreasing processes using lipase which were incorporated in beamhouse operations. Value a indicates the fat content of the left side of dry salted skin after the normal beamhouse operations, serving as control. Value $b$ indicates that of the right side, after the degreasing process as shown in Fig. 12. Value $c$ indicates that of the right side after the degreasing process and subsequent degreasing with kerosine.

\begin{tabular}{|c|c|c|c|c|c|c|c|c|c|}
\hline \multirow{3}{*}{$\begin{array}{l}\text { Kinds of } \\
\text { degreasing } \\
\text { process }\end{array}$} & \multirow[b]{3}{*}{ Value } & \multicolumn{8}{|c|}{ Fat content of bated pelt $(\%)$} \\
\hline & & \multicolumn{2}{|c|}{ Shoulder } & \multicolumn{2}{|c|}{ Belly } & \multicolumn{2}{|c|}{ Butt } & \multicolumn{2}{|c|}{ Whole } \\
\hline & & range & average & range & average & range & average & range & average \\
\hline \multirow[t]{3}{*}{1.} & a. & $9.6 \sim 10.5$ & 9.9 & $6.8 \sim 7.8$ & 7.4 & $7.3 \sim 8.2$ & 7.8 & $8.1 \sim 8.8$ & 8.4 \\
\hline & b. & $6.6 \sim 7.8$ & 7.3 & $5.3 \sim 7.2$ & 5.9 & $5.8 \sim 6.5$ & 6.2 & $5.9 \sim 7.2$ & 6.5 \\
\hline & c. & $2.2 \sim 3.0$ & $2 \cdot 5$ & $1.6 \sim 2.2$ & 1.9 & $1.8 \sim 2.4$ & 2.1 & $1.9 \sim 2.5$ & 2.2 \\
\hline \multirow[t]{3}{*}{2.} & a. & $9.7 \sim 10.7$ & 10.2 & $7.7 \sim 8.8$ & 8.3 & $8.0 \sim 9.4$ & 8.3 & $8.5 \sim 9.6$ & 9.1 \\
\hline & b. & $8.2 \sim 9.8$ & 9.0 & $6.3 \sim 7.8$ & 7.2 & $6.7 \sim 8.4$ & 7.6 & $7.1 \sim 8.7$ & 7.9 \\
\hline & c. & $1.8 \sim 2.6$ & 2.2 & $0.9 \sim 1.9$ & 1.5 & $1.4 \sim 2.4$ & 1.9 & $1.4 \sim 2.1$ & 1.9 \\
\hline \multirow[t]{3}{*}{3.} & a. & $9.4 \sim 12.2$ & 10.4 & $7.4 \sim 9.8$ & 8.7 & $8.3 \sim 10.4$ & 9.5 & $8.5 \sim 10.8$ & 9.5 \\
\hline & b. & $3.6 \sim 5.8$ & 4.9 & $3.2 \sim 4.4$ & 3.8 & 4. $4 \sim 5.2$ & 4.6 & $4.0 \sim 5.1$ & 4.4 \\
\hline & c. & $2.4 \sim 3.4$ & 2.6 & $1.4 \sim 2.0$ & 1.7 & $1.4 \sim 2.5$ & 1.9 & $1.9 \sim 2.6$ & 2.1 \\
\hline \multirow[t]{3}{*}{4.} & a. & $9.5 \sim 10.8$ & 10.2 & $7.0 \sim 8.8$ & 8.1 & $8.8 \sim 9.4$ & 8.9 & $8.3 \sim 9.5$ & 9.4 \\
\hline & b. & $3.5 \sim 5.2$ & 4.0 & $2.0 \sim 3.1$ & 2.5 & $2.4 \sim 3.7$ & 2.9 & $2.8 \sim 3.6$ & 3.1 \\
\hline & c. & $1.9 \sim 3.5$ & 2.3 & $0.6 \sim 1.6$ & 1.1 & $1.1 \sim 2.4$ & 1.8 & $1.2 \sim 2.6$ & 1.7 \\
\hline
\end{tabular}

The results were obtained from 5 pieces of skin for each degreasing process.

象としてリペーゼによる実用的な脱脂方法を椧討した。 すなわ⿱りパーゼ処理赏組み込んだ4通りの準備作業方

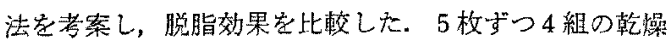
程藏皮を使用し，车半裁は通常の準備作業を施し対照と
した. 右半裁はFig. 12 に䓃載した 4 通りの方法でリハ

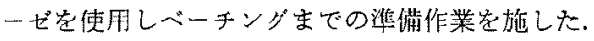

ショルダー部，ペリ一部执よびバッ卜部より小皮片定 探取して脂肪含量学測定した。度の残部はヶロシン $10 \%$ 
周村・白詊・川村

Process 1. (lipase was used in soaking)

$$
\begin{array}{lrl}
\text { Soaking : } & 300 \% & \text { water }\left(25^{\circ} \mathrm{C}\right) \\
& 3 \% & \text { sodium chloride } \\
0.1 \% & \text { sodium hydroxide } \\
0.3 \% & \text { nonionic surfactant } \\
40 \mathrm{u} / \mathrm{g} & \text { lipase }
\end{array}
$$

run for 20 minutes, keep standing for an hour, run for 10 minutes and keep standing. for 20 hours, then wash for 20 minutes. (\% based on the salted weight)

Process 2. (lipased was used in reliming)

$$
\begin{array}{ccl}
\text { reliming : } & 200 \% & \text { water }\left(25^{\circ} \mathrm{C}\right) \\
& 4 \% & \text { calcium hydroxide } \\
& 0.2 \% & \text { nonionic surfactant } \\
& 40 \mathrm{u} / \mathrm{g} & \text { lipase }
\end{array}
$$

steep in the bath for 2 days using drum, with rotation 3 times a day for 10 minutes. each. (\% based on the limed weight)

Process 3. (lipased was used in deliming bating)

$$
\begin{array}{lll}
\text { deliming : } & 200 \% & \text { water }\left(35^{\circ} \mathrm{C}\right) \\
& 0.3 \% & \text { lactic acid, run for } 10 \text { minutes } \\
& 0.2 \% & \text { nonionic surfactant } \\
& 0.8 \% & \text { ammonium sulfate, run for } 10 \text { minutes } \\
& 0.1 \% & \text { Oropon } \mathrm{N} \\
40 \mathrm{u} / \mathrm{g} & \text { lipase, run for } 2 \text { hours, wash ( } \% \text { based on the limed weight) }
\end{array}
$$

Process 4. (lipase was used in bating)

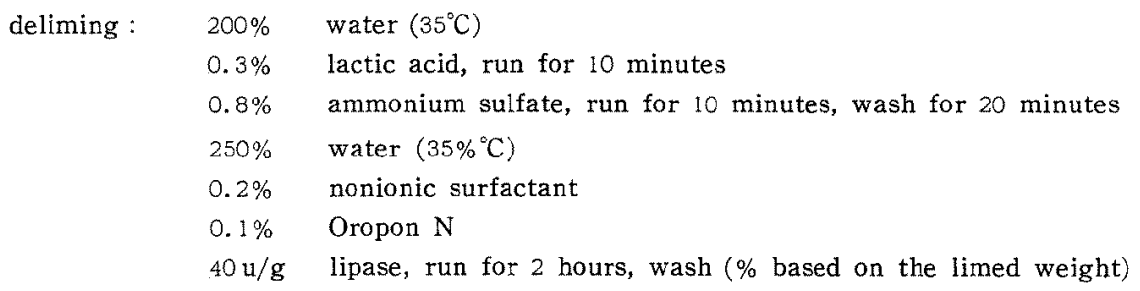

Fig. 12. Processes for degreasing pigskin using lipase.

と非イオン活性刜 $1.5 \%$ 乙共に 1 時間回标, 水 $\left(25 \sim 30^{\circ} \mathrm{C}\right)$ $100 \%$ 定添加し，30 分問ドラム娄回転してから 30 分間水 洗した，脂肪含量の測定結果等 Table 5 に示示。

リパーゼを準備作業に使用する場合, 脱灰後べーチン

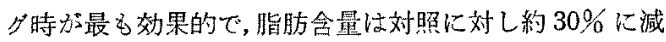
少した．水ゔけまたは石灰づけ特にリパーゼを使用して る效果㔔少ない、リパーゼを使用して準備作業を施した 後，ヶロシン它用いて再度脱脂すると脂肪合量は更に低 下し、リパーゼ処理の差異によらず約 $2 \%$ となった。し

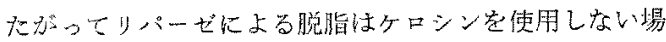

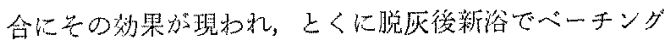
用之其红回忶する方法加良い。
本研究の内容は昭和 49 年度 日本農芸化学会大会にお いて発表した。なお本研究に当たり，リパーゼの試料密 提供され，助言を载いた東洋酾造（秼），管理統制室手塚 隆久氏に感謝いたします。

\section{文献}

1）元吉治雄・諸橋悠紀治 - 岡村 浩, 皮革化学 $\mathbf{1 6}$ : 247-250. 1971.

2）山田浩一・太田安英・町田晴夫，農化 36：860. 1962.

3）赤堀四郎編，睛素研究法 $\mathrm{p} 238$. 朝倉畒店. 東京. 1956.

4）白井邦郎 - 浆 国樑 - 岡村 浩, 日畜会報 43: 611-619. 1972.

5）白井邦郎 - 蔡 国樑・岡村 浩, 日音会報 44 470-475. 1973. 


\title{
Changes in Pigskin Fat Content During Beamhouse Operations and Degreasing with Lipase
}

\author{
Hiroshi Okamura, Kunio Shirai* and Akira Kawamura
}

Lea, her Research Institute, Tokyo University of Agriculture and Technology, Tokyo-to 183

*Yamazaki Chemical Laboratory, Saitama-ken 340

It is important to examine some methods of degreasing pigskins to utilize them as leather materials of high quality. Fat content of pigskin is generally more than $20 \%$ on the dry weight basis, which is higher than that of heavy cattle hide. The differences of fat content among the locations of pigskin were not evident. Fat content of pigskin after the normal beamhouse operations was $6 \%$ and the decreasing of dry salted skin was more difficult. If the reliming period was less than 3 days, treatment of the delimed peit with lipase by adding $40 \mathrm{u} / \mathrm{g}$ of lipase and drumming was effective for degreasing and the fat content reduced to about $3 \%$. 